\title{
Application of Ceramic Wastes in Concrete
}

\author{
Qu Shuying, Zheng Bin ${ }^{*}$, Sun Chen and Li Jin
}

School of Civil Engineering, Yan Tai University, Yan Tai, China

\begin{abstract}
Environmental issues have been of concern. The rapid development of the construction industry and ceramics have become a major source of national income. The unreasonable development patterns have brought certain environmental pollution. How to reduce pollution to the minimum and to make some reasonable economic use is a significant subject in the field of Waste disposal and resource recovery. This article is based on the present situation of application of fly ash in concrete. Test the application of ceramic waste materials in the concrete to get some application value.
\end{abstract}

Keyword: Ceramic Wastes, Concrete, Environmental Pollution, Resource Recovery, Secondary Use

\section{INTRODUCTION}

The concrete as the world's largest amount of man-made materials is the preferred material that cannot be replaced in twenty-first Century for all kinds of infrastructure construction, but with the increasing amount of concrete, the consumption of natural resources such as sand and gravel aggregate are also increasing rapidly. It is estimated that the consumption of concrete industry is now at an annual rate of about 5 billion tons of natural aggregate, sand and gravel has become one of the largest amount of raw materials. A lot of mountains, quarrying has severely damaged the natural mountain landscape and green vegetation. Digging river sand has changed the bed position and shape, resulting in serious consequences, such as soil erosion or river diversions. Since many countries and regions have no merit even gravel and sand, concrete aggregate resources in a serious crisis. In response to this situation, people began to seek new aggregate resources, and has achieved some success, for example, the system of sea sand aggregate, waste concrete recycled aggregate, the used tailings production of aggregate, artificial aggregates [1-3].

In the production, transportation, sale, storage and use of all kinds of ceramic products during the period, due to the bump, eliminate aging and other factors cause a lot of waste ceramics. Literature survey showed [4], 30\% of the world's ceramic industry product as industrial waste. Ceramic industry as a traditional industry in China, the amount of waste is high. But this part of ceramic waste, according to the present, doesn't have any form of effective recycling.

In order to meet the economic development and people's living needs, ceramic industry and construction still have to continue to develop, so caused by the traditional concrete production of ceramic waste pollution and how to effectively

*Address correspondence to this author at the School of Civil Engineering, Yan Tai University, Yan Tai, China; Tel: 13553145946; 15275560504;

E-mail: qsy_qu@163.com; zb199088@qq.com use the ceramic waste have become an urgent problem nowadays, how to apply the ceramic waste generated by the ceramic industry effectively in the construction industry production of raw materials is an important issue in the field of waste treatment and resource recovery. Reusing ceramic waste powder in building material production is not only to more efficient use of resources, and reduces the pollutant emissions, but is conducive to the sustainable development of society and nature. It is believed that mixing of readymixed concrete products with ceramic powder waste to some extent can be considered environmentally friendly concrete. Mizuguchi [5], Wang Xingchang [6] think: environmental protection concrete is to be able to reduce environment load while improving the ecological environment in harmony with nature, and to contribute to environmental protection of concrete.

\section{PRECEDENT UTILIZATION OF FLY ASH}

The developed countries in the world have paid much attention to the recycling and reuse of the waste material much earlier. On the one hand, these countries are relatively short of resources and they need to recycle the waste materials to reuse, on the other hand the environmental protection consciousness of the government and the people are very strong and the consciousness is high. It promote the adoption of new technology, new method to use the waste material in the production of the building materials such as the production of the cement and the wall materials, to control the solid waste materials in a small amount [7]. In the research and utilization in waste concrete admixture, in 1980s, Prof. R.E. Davis suggested the Fly ash concrete technology and became a leader in the field. After that the United States, Britain, France, Japan and other countries used the fly ash respectively in water conservancy projects and its working performance has done well until now. The $\mathrm{HeMa}$ dam is a very large engineering project which have proved to be a milestone in the history of the development of fly ash concrete. Although the scope of the repeated application of fly ash is very wide, but until 1960s, the 
Britain and the United States and other countries formulated the dosage of fly ash concrete in the form of national standards formulation. In 1990s Prof. Malhotra [8] and his partners added a lot of Fly ash in the Concrete blocks and carried out a lot of experiments. According to the different fly ash admixture proportion and the cement level, the experimental results showed that as far as possible to reduce consumption and increase the dosage of fly ash cement at the same time adding air-entraining agent and water reducing agent and working performance of concrete block was obviously higher than that of adding a large number of high level cement block experiment. Prof. Paya [9-10] and his team carried on the experimental study of adding the fly ash into concrete. After five years of research and a large number of experiments, they come to the conclusion that the grinding particle size of fly ash should be higher than $30 \mu \mathrm{m}$, through grinding of a few minutes to get the raw materials size less than $10 \mu \mathrm{m}$, as grinding the Block work performance enhancements, and in $20^{\circ} \mathrm{C} \sim 60^{\circ} \mathrm{C}$ the growth rate of the strength of the block increased but it was not obvious above $80^{\circ} \mathrm{C}$.

And the research of fly ash concrete in China is relatively late of 30 years than western countries, Shen Danshen [11] and other experts adjusted measures to local conditions of the mass fly ash concrete to put forward that it should be applied to engineering practice until the $1950 \mathrm{~s}$. From 1950s to the early 1980s, in spite of that the fly ash concrete has been extensively used in engineering projects but they did not get the results of theory research until the mid-1980s. Shen Danshen [11] and others put forward the "secondary reaction" and "three effectiveness" based on the "fly ash effects". Gao Fengling [12] got the fly ash particle diameter less than 45 which increase the intensity of concrete block and the working performance at the same time by the Powder particles in air separation experiment method. Tong Xueli [13] and others found in the process of steam cured concrete research that the blocks which were adding fly ash concrete were stronger in corrosion resistance than the ordinary concrete blocks. At present in China the study of fly ash concrete and the use of promotion also reached as high as the international level, a number of national standards and voluntary national standard to guide the production and design that has been formulated.

\section{THE USE OF CERAMIC WASTE}

In 1980, American government enacted the Superfund Law [14] and one of the regulations points out that enterprises must timely and reasonably deal with all the possible affiliated wastes during the process of producing ceramics, through which America has formed the primary way that enterprises solve the problem by themselves and government leads inspection. In America, more that $40 \%$ ceramic wastes will be recycled and the remaining ones will be made into ceramic powder and will be provided to other factories which can use it [15]; Relevant data provided by the British Ceramic Research Association show that the recycling rate of most ceramic factories has reached to $40 \%$. The primary way of reutilization is to reprocess the wasted porcelains and add them into the production of new porcelains. If the product is white ceramic tile, we cannot use the red or other dark-colored ceramic wastes and in this case factories which process wasted ceramics and materials will contact the tile factories any time. This technology of processing and reusing wasted ceramics has wined the favor of ceramic specialists, environmentalists and government and has won several prizes [15]. Enterprises in Japan pay a lot of attention to the ceramic wastes during the producing process and insist on reprocessing and recycling. Due to the scarcity of resources and strong environmental awareness, Japan has begun the study on using ceramic wastes 10-20 years earlier than China and has relatively mature dealing technology. Many transnational corporations, such as Inax, have begun to utilize ceramic wastes and used them to make porous thermal insulation building materials by mixing the polished wastes with other materials. The usage has almost reached $100 \%$ [16-17]. In recent years, most ceramicsbuilding enterprises have applied belt-type rotary mill device into the producing process and have gained relatively conspicuous economic and environmental benefits [18].

In 2003 RM.Senthamarai et al [19] designed the experiments on waste ceramic pieces completely replace the traditional coarse aggregate, which sets the maximum size of coarse aggregate value of 20 . The experimental results show that: Although alternative experimental group has advantage in low tension and compression ratio and workability, but in the compressive strength, splitting tensile strength, flexural strength the alternative ones are lower than the traditional raw materials of concrete $3.8 \%, 18.2 \%$ and $6 \%$, respectively. Similarly, in the study of alternatives to traditional coarse aggregate by ceramic scrap, Portuguese scholars J.de Brito and A.S. Pereira [20] did more detailed experiments, respectively using ceramic pieces of $1 / 3,2 / 3$, and completely traditional coarse aggregate. The experimental results showed that: the wear of alternative group got enhanced, but the set of alternative concrete block's compressive strength and flexural strength decreased with the increase of replacement ratio, and the reduction value of the compressive strength was higher than the reduction value of the flexural strength.

In the study of ceramic waste instead of fine aggregate, pieces of ceramic waste are always reprocessed firstly, which will be polished to become the fine aggregate as the particle with maximum size of $4 \mathrm{~mm}$. Spanish Hanifi Binici [21] and V. Lopez [22], using different substitution rate of $40 \% \sim$ $60 \%$ and $10 \% \sim 50 \%$ did mechanics experiment respectively, their experimental conclusion showed: In wear resistance, workability and resistance of the chloride ion penetration, the concrete group of substitution is better than traditional concrete, and with the increase of replacement ratio, the compressive strength increased, and was higher than that of conventional concrete.

At present, the research on ceramic concrete of domestic scholars is not much, and the beginning of reusing research is relatively late. The gap of current technology exist between our country and the international advanced countries, mainly on the utilization of waste products:

\section{(1). Application of Ceramic Tiles and Ceramic Production Areas}

Liu Zhiguo [18] and Li Yufeng [23] think that the production of ceramic tiles is mainly used to produce billets 
and antique brick tiles. Given the quality and purity of ceramic powder has changed and cannot reach the high standards. We can only process some simple and extensive relatively blank using in tile and antique brick production by some initial and simple processing, such as recycling, picking debris, removing iron. Guangdong Aihetao Ceramics Co., Ltd. was subjected to the department of environmental protection many times previously because of the inability to procession and utilization of output ceramic waste by the production of the pipeline. Through the efforts of the company's technology department, they used the residual waste blanks and waste sludge in production line after a certain treatment to antique the brick blank. In addition for saving the cost of raw materials, the treatment cost of waste and waste mud slab was reduced while production costs was reduced and met environmental requirements.

Porous ceramics and sanitary ceramics are main in the applications of ceramic production. Due to the low quality of ceramic waste similarly, researchers such as Han Fuxing [24] etc introduced the main production methods in their study of the application. First, the ceramic powder processed into powder, then by adding the other ingredients, ultimately into the mold and fired forming at high temperatures. Fengxi Ceramic Research Institute in Guangdong province concluded in 2001 based ceramic waste reprocessing and recycling successfully. They determined the ceramic waste porcelain clay - product model primarily and the utilization of waste porcelain is $30 \sim 40$ percent in the test to run the model. In addition, the new product is better than ordinary porcelain clay products in stability, temperature and hardness. It realized the reduction, recycling, harmless of ceramic waste and promoted the sustainable development of Guangdong ceramics industry.

\section{(2). Application of Raw Materials Production of Architecture Industrial}

You can see the ceramic industry waste under the microscope, microscopic morphology of the ceramic waste is an irregular scaly which determines grindability of ceramic particles. After full, moderately coarse broken and surface cleaning with a surfactant impurities, the ceramic waste can get raw materials suiting cement, concrete and other construction materials production and processing. Putting the ceramic waste after reprocessing into cement and concrete production will bring great social and economic benefits and achieve effective integration of ceramic waste disposal with construction materials production. Application are mainly in the production of ceramic and wall insulation board by ceramic waste and preparation of concrete and padded liner insulation aspects [7, 25-26].

\section{(3). Applications on the Concrete}

In theory research, Tang Ming and Pan Wenhao [27] did experiments to research the mechanics of the concrete that consisted of reclaimed sand of waste ceramic pieces and fine aggregate, experiments results showed that: the traditional concrete which sand and fine aggregate were replaced by ceramic waste and kept its compressive strength from reducing, even slightly higher than that of traditional with proportioning of concrete bloc, but the task blocks behaved worse on the workability, cohesiveness, water-retaining property and flexural strength.

Li Lixia [28] grinded fully trash ceramics to small particle size of powder particles, then carried out experiments about the feasibility of mixing powder particles into concrete and cement. Results showed that: cement and concrete mixing with powder particles was feasible and the production technology needed no change, its technology is feasible and economically reasonable. When the ratio of the powder particles are controlled under $30 \%$, slumps, cube compressive strength and carbonization of the concrete task blocks are superior to cement group, but the best ratio should be controlled within $20 \% \pm 10$, considering to ensure the durability, cube compressive strength and workability of concrete task blocks and economic efficiency comprehensive.

Table 1. Concrete Experiment Program unit: Kg.

\begin{tabular}{|c|c|c|c|c|c|c|c|c|}
\hline No. & Sand & Gravel & Cement & Slag & $\begin{array}{l}\text { Ceramic } \\
\text { Powder }\end{array}$ & Coal Ash & $\begin{array}{l}\text { Polycarboxylate } \\
\text { Superplasticizer }\end{array}$ & Water \\
\hline $\mathrm{J}-1$ & 980 & 960 & $\begin{array}{c}\text { P.C } 32.5 \\
230\end{array}$ & 80 & 0 & 60 & $\begin{array}{c}2.1 \% \\
7.8\end{array}$ & 84 \\
\hline $\mathrm{J}-2$ & 980 & 960 & $\begin{array}{c}\text { P.C } 32.5 \\
230\end{array}$ & 0 & 80 & 60 & $\begin{array}{c}2.3 \% \\
8.5\end{array}$ & 84 \\
\hline $\mathrm{J}-3$ & 980 & 960 & $\begin{array}{c}\text { P.C } 32.5 \\
250\end{array}$ & 0 & 60 & 60 & $\begin{array}{c}2.2 \% \\
8.2\end{array}$ & 84 \\
\hline $\mathrm{J}-4$ & 980 & 960 & $\begin{array}{c}\text { P.O } 42.5 \\
230\end{array}$ & 80 & 0 & 60 & $\begin{array}{c}2.3 \% \\
8.5\end{array}$ & 90 \\
\hline $\mathrm{J}-5$ & 980 & 960 & $\begin{array}{c}\text { P.O } 42.5 \\
230\end{array}$ & 0 & 80 & 60 & $\begin{array}{c}2.5 \% \\
9.3\end{array}$ & 90 \\
\hline $\mathrm{J}-6$ & 980 & 960 & $\begin{array}{c}\text { P.O } 42.5 \\
250\end{array}$ & 0 & 60 & 60 & $\begin{array}{c}2.4 \% \\
8.9\end{array}$ & 90 \\
\hline
\end{tabular}


In this regard, the author mainly compares experiments using the method of experimental exploration of mechanical properties of cement mortar and concrete which is made secondary in the use of ceramic powder of polished ceramic tiles produced from a ceramic production line. The material constitution for the concrete experiment was done in accordance with Table $\mathbf{1}$.

There were at least three test blocks in each of the test block groups mixed in different ratios to undergo $3 \mathrm{~d}, 7 \mathrm{~d}$ and $28 \mathrm{~d}$ compressive strength tests, $28 \mathrm{~d}$ splitting tensile strength test and $28 \mathrm{~d}$ flexural strength test respectively. Among them 129 blocks received standard curing. Experiment to determine other general features were conducted more than 800 times. A lot of experiments and data analysis showed the following results.

In the experimental groups of the same ratio where ceramic powder served as a concrete admixture, despite different grades of cement mixed the measured slump of the experimental groups were basically the same. The ceramic powder-doped group's slump was minimal, but $1 \mathrm{~h}$ slump loss was larger, liquidity was the worst among the three. The mechanical experiments were mainly compressive to strengthen the test, splitting tensile strength test and flexural strength test. In the actual process of concrete application, these three experiments could basically meet the designed needs: analysis of $3 \mathrm{~d}, 7 \mathrm{~d}$ and $28 \mathrm{~d}$ compressive strength tests on six groups of the same ratio showed that the compressive strength value measured at three different times and was the lowest in the group fully using ceramic powder and the highest in the slag-doped group. The ceramic powder-doped concrete group saw a fast increase in strength in early period than in the later period, and the group mixed with high-grade cement saw faster increase in strength than the group mixed with low-grade cement. When mixed with low-strength cement, the amplitude of increase in strength varied with $7 \mathrm{~d}$ as the threshold and when mixed with high-grade cement the strength showed little difference between the early and later periods of the curing duration; splitting tensile strength of concrete experiments showed that a mixed use of ceramic powder and high-strength cement could better play a role, though the effect was still not as good as cement and slag, but the results still met the actual needs of laboratories and engineering; ceramic powder was mixed with high-strength and low-strength cement successively, and the results showed that the flexural strength of the ceramic powderdoped group was not as good as the slag-doped group, but better than cement-doped group.

As can be seen from the above experimental results, the ceramic powder in question can replace slag to a certain extent to be applied in the preparation of concrete, and the mixing effect of the ceramic powder with high-strength cement is better than that with low-strength cement. Also from the point of view of economic efficiency valued more by enterprises the ceramic powder is very attractive. First, the ceramic powder is a byproduct of the production line, requiring only part of the manpower and equipment in the whole process of from output, input and production of concrete without the need to purchase expensive slag raw materials, thereby lowering the production costs; Secondly, the experiments confirmed that the ceramic powder has superior flexural strength to cement to some extent, so in the design of large-span structures and components, cement can be replaced by a certain amount of ceramic powder, so that the concrete block mixed with ceramic powder in certain ratio has higher flexural strength than the average conventional concrete of the same grade; Thirdly, ceramic powder-doped concrete sees faster increase in the strength in the later period than the average, and when mixed with highgrade cement ceramic powder-doped concrete also sees faster increase in strength in early period than the average, thus is especially suitable for structural engineering with requirements for strength in early period; Finally, the larger specific surface area of ceramic powder makes it less liquid, thus in the preparation of concrete for special requirements the ceramic powder herein can be added to reduce the slump of the concrete and increase the performance of ceramic powder-doped concrete.

\section{CONCLUSION}

People pay attention to environmental protection in the $21^{\text {th }}$ century, and higher demands are being raised for environmental protection with China carrying out strategy of sustainable development. Reducing environment pollution and recycling of the ceramic waste are environmental protection of industries' two main development directions. Possibility of ceramic waste use in concrete can be seen from the precedent of the usage of fly ash that is also waste, based on the existing research results of ceramic waste and the experiment research of ceramic waste using in concrete. Our country as the world's largest ceramics producer and according to our country needs much concrete is needed to support our development at high speed, but reserves of our country' non-renewable resources are close to the red line. If ceramic waste can be used fully, not merely environment damage will occur, but also concrete production cost can be reduced. Twin purposes that contain solving the huge environmental crisis and the sustainable development of both society and economy can be reached.

\section{CONFLICT OF INTEREST}

This article content has no conflict of interest.

\section{REFERENCE}

[1] K. Yan, "Expand the application of industrial waste in concrete engineering," Journal of Building Construction, vol. 21, no. 2, pp. 56-57, 1999.

[2] C. Zhang, "Problems and countermeasures of environment resources of concrete material," Journal of Building Technique Development, vol. 6, pp. 6-8, 2000.

[3] J. Yang, "Ponderation on the development of concrete science in the future," Journal of Concrete, vol. 3, pp. 3-9, 2001.

[4] Y. Sun, "The present study state and problems to be solved on recycled concrete in china," Concrete, vol. 4, pp. 25-28, 2006.

[5] H. Mizuguchi, "A review of environmentally friendly concrete," Journal of Concrete, vol. 36, no. 3, 1998.

[6] X. Wang, "Experimental study of the preparation of ecological concrete using waste fly ash," Master's thesis, School of Civil Engineering of Shandong Jianzhu University, 2012.

[7] D. Wan, and G. Peng, "Research on the concrete material development by using ceramic waste," Journal of Fo Shan Ceramics, vol. 11, no. 10, pp. 4-6, 2001.

[8] Q. Sun, "The characteristics of concrete with high volume of flyash," Journal of Si Chuan Institute of Building Research, vol. 2, pp. 16-23, 2006. 
[9] J. Paya, J. Monzo, M.V. Borrachero, E. Peris-Mora, "Mechanical treatment of fly ashes.part I : physico-chemical characterization of ground fly ashes," Cement and Concrete Research, vol. 25, no. 7, pp. 1469-1479, 1995.

[10] J. Paya, J. Monzo, M.V. Borrachero, and E. Peris-Mora, "Mechanical treatment of fly ashes. part II : particle morphologles in ground fly ashes(gfa)and workability of gfa-cement mortars," Cement and Concrete Research, vol. 26, no. 2, pp. 225-235, 1996.

[11] D. Shen, and Y. Zhang, "A study of the effects of fly ash," Journal of The Chinese Ceramic Society, vol. 9, no. 1, pp. 57-63, 1981.

[12] F. Gao, "Ultra-fine ash air separation technology and application benefits," Journal of Fly Ash Comprehensive Utilization, vol. 1, pp. 1-3, 1998.

[13] X. Tong, and C. Liao, "Research on the corrosion resistance of steam curing fly ash silicate materials and slag silicate materials, " Journal of The Chinese Ceramic Society, vol. 2, no. 1, pp. 40-47, 1963.

[14] A. Xu, A. Shayan, and P. Baburamani, "Test methods for sulfate resistance of concrete and mechanisms of sulfate attack. reports," Journal of ARRB Transport Research, pp. 38-39, 1998.

[15] A. Yu, and $\mathrm{K}$. Yu, "The recycling of ceramic waste materials and eco-material science," Journal of Ceramics, vol. 7, pp. 11-12, 2008.

[16] L. Zeng, X. Jin, and Y. Liu, "A review of recycling technology for ceramic wastes," Chemical Industry Press, Beijing, 2010.

[17] J.L. Amoros, M.J. Orts, and J. Garca-Ten, "Effect of the green porous texture on porcelain tile properties," Journal of the European Ceramic Society, vol. 27, pp. 2295-2301, 2007.

[18] Z. Liu, "Industrial waste used in ceramic tile billet," Journal of Fo Shan Ceramics, vol. 5, pp. 33-34, 2003.
[19] R.M. Senthamarai, "Devadas $m$ p.concrete with ceramic waste aggregate," Journal of Cement and Concrete Composites, vol. 27, pp. 910-913, 2005.

[20] J. de Brito, A.S. Pereira, J.R. Correia, "Mechanical behaviour of non-structural concrete made with recycled ceramic aggregates," Journal of Cement and Concrete Composites, vol. 27, pp. 429-433, 2005.

[21] H. Binici, "Effect of crushed ceramic and basaltic pumice as fine aggregates on concrete mortars properties," Journal of Construction and Building Materials, vol. 21, pp. 1191-1197, 2007.

[22] V. Lopez, B. Llamas, A. Juan, "Eco-efficient concretes : impact of the use of white ceramic powder on the mechanical properties of concrete," Journal of Biosystems Engineering, vol. 96, no. 4, pp. 559-564, 2007.

[23] Y. Li, "Development and utilization of ceramics factory waste," Journal of Fo Shan Ceramics, vol. 3, pp. 16-18, 2003.

[24] F. Han, "Research on the production of porous ceramic by using ceramics factory waste," Ceramic Studies Journal, vol. 1, pp. 2427, 2002.

[25] Facai, "Residue ceramic powder for cement production," Journal of Practical Technology, vol. 5, pp. 35-36, 1995.

[26] L. Yu, J. Wu, Y. Li, and C. He, "The experimental study of cement mixed material by useing ceramic waste materials," Journal of Cement, vol. 10, pp. 10-11, 2004.

[27] M. Tang, and W. Pan, "Characteristics of the strength of ceramic waste sand concrete," Journal of Concrete, vol. 218, no. 12, pp. 13, 2007.

[28] L. Li, "Ceramic waste powder in the study of the optimal dosage of the concrete," Journal of China Ceramics, vol. 46, no. 5, pp. 19-21, 2010 .

(C) Shuying et al.; Licensee Bentham Open.

This is an open access article licensed under the terms of the Creative Commons Attribution Non-Commercial License (http://creativecommons.org/licenses/ by-nc/3.0/) which permits unrestricted, non-commercial use, distribution and reproduction in any medium, provided the work is properly cited. 